\title{
INNOVATIVE POLICY IN THE FIELD OF PERSONNEL TRAINING IN THE CIVIL SERVICE
}

\author{
Alexey Baranov ${ }^{1}$, Olga Kotlyarova ${ }^{2}$, Alexey Tagaev $^{3}$
}

\begin{abstract}
The hypothesis of the presented article is the idea that the innovation policy in the field of public administration personnel training is based on two principles: 1) training of personnel of a new format, corresponding to the requirements of reality and ready for quick and not always anticipated changes, 2) careful attitude to the human resource, that is, the human potential of the public administration system. The introduction describes the archaic system of Russian personnel policy. The introduction of relevant principles into the state personnel policy will improve the professional competencies of employees, adapt them to the process of changes in public administration, and allow interested employees to plan and build a career perspective. The formulated principles are a consequence of the teamwork of the educational organization and government authorities in order to understand new staffing requirements for the public administration system. These principles include the principle of corporate training, the principle of customizing educational content, the principle of personalizing additional professional programs, the expert principle, the principle of innovative methodology, the blended format principle, the motivational principle, the principle of independent assessment of the quality of training of students, the principle of independent assessment of the quality of conditions, the principle of internal evaluation systems, analysis principle. In conclusion, the author substantiates the statement that it is necessary to expand the range of fundamental principles in connection with the openness and dynamism of the structure of innovative personnel policy.
\end{abstract}

UDC Classification: 351, DOI: https://doi.org/10.12955/pss.v2.200

Keywords: innovation policy, personnel policy, additional professional education.

\section{Introduction}

The training of personnel in the field of public administration has its specifics. First of all, the system of personnel policy in the civil service is characterized by tradition, dogmatism, archaism, and lack of flexibility. Such an anti-dynamism of the personnel system is associated with the management tradition. In Russia, current civil servants are guided by a stereotypical understanding of the proper behavior and thinking of a representative of the authorities. To a greater extent, this is due to 1) the rigid official hierarchy and subordination of the public administration system, 2) the need to act strictly within the framework of regulations (legislation, job descriptions, bureaucratic process, etc.), 3) image standards: the speech and behavior of a civil servant with the acquisition of experience become formulaic, typed. Civil servants who have re-entered the public administration system, within a few years, adapt and undergo professional deformation. The result is the adaptation of the subject to the system. A civil servant in his professional activity is not guided by the principles of efficiency and effectiveness, but, first of all, bases the choice of a decision on the principle "it is necessary, it is necessary, it is so accepted", which means that it is so correct. The innovation of the personnel policy is primarily regulated by the principle of training personnel in a new format. The human resource in the political sphere should play a crucial role, and not be a structural element of the system. In connection with the current changes in the socio-economic development of the Russian state, in connection with the large-scale processes of globalization and digitalization of world processes, in connection with the need to comply with advanced international standards in the field of public administration, there is an obvious need to change the personnel potential of the civil service.

The primary factor in the effective functioning of the state is the well-being and comfort of the population, the existence of trusting and stable relations between citizens and the authorities, and the confidence of representatives of civil society in their own security. To achieve these goals, this area must be managed by personnel of the new format. The new format of representatives of power structures implies 1) understanding of their own importance in the public administration system, awareness of individual and collective responsibility, 2) possession of relevant and demanded professional competencies that allow to prevent and eliminate unstable situations at various levels of the public

\footnotetext{
${ }^{1}$ South-Russian Institute of management - branch of The Russian Presidential Academy of National Economy and Public Administration, Rostov-on-Don, Russian Federation, bav.skags@ gmail.com, ORCID: 0000-00033004-9684

2 Vladimir Branch of The Russian Presidential Academy of National Economy and Public Administration, Vladimir, Russian Federation, olya-apriori@yandex.ru, ORCID: 0000-0002-5077-6339

${ }^{3}$ South-Russian Institute of management - branch of The Russian Presidential Academy of National Economy and Public Administration, alvasta13@yandex.ru, ORCID: 0000-0003-1190
} 
administration system, 3) quick adaptability, flexibility and learning in accordance with a changing situation and many others. However, one cannot but pay attention to the fact that practical experience of work in the system of public administration has a special value for human resources.

In the opinion of the team of authors, these principles are the vector of innovation policy in the field of personnel development. In this regard, it is difficult to form a new format of civil servants in the process of obtaining higher education (there is no practical and experienced component). The new format of the civil service personnel is determined by a dynamic system of constantly updated professional competencies combined with practical experience. From this point of view, the innovative policy of forming a new format of personnel is within the framework of additional professional education.

\section{Literature review}

Innovation policy at the stage of modern world development affects all scientific areas. Moreover, it is difficult to differentiate certain directions in connection with their diffuseness and interdependence.

Thus, the innovativeness of economic development affects the areas of business and creates conditions for the dynamism of the innovative potential of the most competitive enterprises and organizations (Iakubov 2007). Integrating scientific and educational spheres into economic processes enhances the innovative component of business structures (Korshunov, Iur'ev 2013). The meaning of innovative business development is to create a collaborative approach. The interest and teamwork of structures of various orientations strengthen the business component and opens up new prospects for achieving positive economic and social effects.

The specifics of national and regional innovations occupy a leading place in modern science (Chumachenko 2012). Researchers talk about new formats for the development of innovative clusters, determined by the territorial and regional characteristics of (Naz'ina 2016). Such innovative clusters are determined by the regions' natural, economic, human, and other resources; however, general patterns of crisis and breakthrough development of innovative clusters are also revealed (Sukhovei, Golova 2016).

The field of innovation is especially popular in the educational paradigm. The development of science, in general, implies an innovative component and is based on the creative potential of representatives of the scientific world interacting with technological advances and artificial intelligence (Artamonova, Demchuk, Karneev, Safonova 2018). Scientists are interested in organizational and managerial mechanisms for the innovative development of universities and educational organizations (Pavlenko 2013), as well as the use of social management technologies for the effectiveness of educational dynamics (Zeinalov, Starodubtseva 2013), (Remorenko 2011).

In the opinion of the author's team, a particularly promising scientific area of innovation policy is research in the field of training competent personnel. The effectiveness of human capital management implies the use of certain financial, organizational, and information resources (Roshchin, Solntsev, Vasil'ev 2017). Human capital is considered as a decisive factor ensuring the comprehensive implementation and promotion of innovations in socially significant areas of the life of modern society (Alekseeva, Gil'dingersh 2018), (Beliakova, Neumoeva-Kolchedantseva 2010), (Bubnov 2016). In connection with the foregoing, innovative personnel policy in public administration is of particular importance for the harmonious dynamics of society and power (Gazieva, Ballod 2018), (Kotliarova, Mironenko 2019).

\section{Data and methodology}

It should be noted that the innovative personnel policy in public administration is aimed at training personnel capable of regulating the processes of interaction between civil society and the state, increasing the satisfaction of citizens, preserving and improving the image component of the government. This orientation implies increased requirements for the quality of interaction, civil servants' responsibility, and the requirements for the effectiveness of ongoing processes.

On the other hand, the main aspect of innovative personnel policy is the need to preserve human capital and increase personnel's emotional and intellectual resources. From this point of view, the principle of "careful professional development" becomes decisive in the development of innovative personnel policy. Such careful development is possible in the format of additional professional education, taking into account the relevance and demand for the skills acquired, the satisfaction of the customer's 
educational request, the timeliness of mastering the relevant programs, the complexity, consistency, and continuity of the acquired professional competencies.

The team of authors in the process of implementing additional professional programs for civil servants is guided by the following principles: 1) additional professional education must comply with the innovative personnel policy of the Russian state; 2) the main priority of the process of obtaining additional professional education is the preservation of human capital, that is, the intellectual resource of civil servants.

Let's comment on each principle. Within our research framework, innovative personnel policy in public administration implies a systematic and continuous process of training employees. The quality of the human resource is determined by the competence potential of the current civil servants. Innovative personnel policy in public administration is in the focus of the research interest of representatives of the Presidential Academy; see, for example, research (Baranov, Tagaev, Ivleva, Kotlyarova 2018); (Gazieva, Shoptenko 2020); (Ovakimyan, Baranov, Kotlyarova 2018).

The principle of saving human capital is understood as an orientation towards preserving and increasing existing civil servants' intellectual capabilities and professional potential.

According to the team of authors, the innovativeness of personnel policy presupposes an informal approach to the acquisition and development of professional competencies of civil servants. Such an approach should take into account 1) the educational needs of students of additional professional programs, 2) competence gaps that require the greatest attention in the learning process, 3) the practiceorientedness of the acquired skills, which subsequently make it possible to effectively act in real situations, 4) the opinion of students. The last criterion is especially significant.

Our research results are the conviction that civil servants holding various positions and having a variety of professional experience can objectively and critically assess their own competence and potential. This means that the personnel training process must necessarily include a criterion for self-assessment of the effectiveness of acquiring additional professional education.

The latest relevant changes in Russian legislation in the field of public service are aimed to improve the system of professional development of management personnel. So, in accordance with the latest edition of the Federal Law "On the State Civil Service of the Russian Federation" №. 79-FZ dated 07.07.2014, "the professional development of a civil servant is aimed at maintaining and improving the level of qualifications necessary for the proper performance of official duties by civil servants, and includes additional professional education and other professional development activities. " Under "other activities" it is logical to understand the exchange of professional experience, as well as the practical application of the knowledge gained, through which systematic professional development is ensured. Additional professional education is carried out within the framework of state order, within the framework of state order, or at the expense of a state body.

In our opinion, one of the significant factors that improve the system of additional professional education in the field of public administration is the possibility of obtaining an educational certificate, which is a registered document confirming the possibility of obtaining additional professional education for civil servants. The student chooses an additional professional program of interest himself, guided by an individual educational need and his own desires to acquire new competencies.

Also, there is an alternative to choosing a university, institute, or other educational organization included in the register of government service providers to implement additional professional programs for civil servants and provide this service.

The consequence of the discussed changes is the formation of an educational initiative among civil servants themselves, which consists of the decision to improve their own qualifications, to choose a specific additional professional program, as well as an educational organization that implements training. Civil servants have the right to determine their own professional development trajectory, its intensity, and content orientation.

Using the methodology of group interviews to implement additional professional programs for the authorities, a team of authors formulated the basic principles, in our opinion, if not completely, then partially structuring the innovativeness of the policy in the field of training personnel of the new format. 
The study was carried out to implement additional professional programs for the authorities in 20192020.

\section{Results and discussion}

In the process of mastering additional professional programs in the framework of group interviews, the factors that form the principles of innovation policy in the field of personnel training were identified. Relevant principles are formulated:

The principle of corporate training - authorities from the point of view of the category of students represent a special cluster that has its own specifics. In our opinion, it is not correct to implement training of civil servants simply by developing their professional competencies. It is important to apply a corporate approach, perceiving the category of trainees as a system characterized by corporate culture, the presence of a common specific strategic goal-setting, organizational principles, subordinate ethics and other distinctive features. Additional professional programs for government agencies cannot be typed and standard.

The principle of customizing educational content. The term "customized" is used to mean "tailored to the full range of educational needs of the customer". To create such programs, representatives of an educational organization must systematically cooperate with representatives of government agencies, monitor the qualitative and quantitative results of mastering educational programs, and verify the principles of assessment.

The principle of personalization of additional professional programs. Of course, the process of acquiring the required competencies by civil servants is massive; from time to time, difficulties arise for differentiating the content of the program for students holding different positions. However, additional professional programs should include the possibility of creating an individual educational design for each student of the program. The presence of questions of varying complexity, the ability to select and analyze in more detail the most interesting topics, the constant provision of feedback, and other factors contribute to the personalization of the program and increase the motivational activity towards its mastering.

Expert principle. Consideration of expert opinion and participation of experts in the implementation of additional education. Participation in additional professional development programs and professional retraining of invited experts, who are practitioners in specific areas of public administration, increases the quality of the educational product, guarantees the practical significance of training, and makes it possible to exchange experience with experts and colleagues.

The principle of innovative methodology. Implementation of innovative teaching methods and technologies focused on the interactive educational process. Active learning technology implies the construction of the educational process by the students themselves. In the field of state and municipal administration, the problem and project approaches are relevant.

The principle of blended format. Implementation of the blended format, that is, the combination of online and offline approaches in the process of obtaining additional professional education. Direct live communication with a teacher, tutor, mentor becomes inappropriate in the epidemiological period; however, the strict prevalence of the online format violates the close, quick and complete immersion of the listener in the educational process. By connecting online and offline formats, it is possible to maintain the temporal and spatial mobility of obtaining additional professional education but not to lose the personal relationship between students and teachers and organizers of training.

Motivational principle. Support for high motivation of representatives of power structures in obtaining additional professional education, which, in our opinion, can be achieved through the interdependence of the development of competence capabilities and career growth. Civil servants should clearly recognize the need for updating professional competencies.

The principle of an independent assessment of the quality of the conditions of the educational process implies regular activities to assess the material and technical base and material and technical equipment, as well as social and living conditions, confirming favorable conditions for the implementation of educational activities.

The principle of independent assessment of the quality of training of students. The introduction of the principle under discussion allows an educational organization a serious advantage over competitors - 
to objectively assess the level of training of students and the effectiveness of the learning process. The method of independent assessment involves the conduct of examination tests by a non-interested party. It is also topical to use the methods of "blind assessment", which make it possible to exclude the experts' interest in the results of the audit.

The principle of an internal assessment system. Monitoring the quality of education, fixing students' level of knowledge at the beginning and at the end of an additional professional program, conducting an internal assessment, in general, contributes to the quality control of additional professional training programs or professional retraining. Quality control of the provision of educational services requires an organization to develop an extensive system of internal assessment of the quality of education, certified according to the quality management standard (GOST ISO 9001-2015). In accordance with the standard, monitoring of the quality of the educational process should be implemented continuously, be present at every stage of the development of the program, provide for the elimination of shortcomings that reduce the effectiveness of training.

Principle of analysis. The introduction of a system of intellectual reflection is an effective account of past experience and mistakes. Cancellation of compulsory additional education once every three years and the possibility of using a certificate and choosing an additional professional program will eliminate a formalized approach, however, the effectiveness of each program must be objectively analyzed.

\section{Conclusion}

One of the main tasks of the modern Presidential Academy is to improve the quality of additional professional education and, as a result, to increase the effectiveness of professional training for representatives of the public administration. In this regard, the range of proposals for the breakthrough development of the system of additional professional education for state and municipal employees is open and requires constant improvement.

The results of the study indicate an objective and critical assessment of civil servants' own competence capabilities, which is a prerequisite for the development of relevant additional professional programs, focused on the customer's request and contributing to innovative personnel policy. This approach is focused on training personnel of a new format.

\section{References}

Alekseeva, I. A., Gil'dingersh M. G. (2018) Effektivnost' upravleniia chelovecheskim kapitalom na primere tekhnicheskikh vuzov Sankt-Peterburga [Efficiency of human capital management on the example of technical universities of St. Petersburg] Notes of the Mining Institute, vol. 232, 421-427.

Artamonova, Iu. D., Demchuk, A. L., Karneev, A. N., Safonova, V. V. (2018) Sovremennye strategii razvitiia nauki i podgotovki nauchnykh kadrov: mezhdunarodnyi opyt [Modern strategies for the development of science and training of scientific personnel: international experience] Vysshee obrazovanie v Rossii, vol. 4, 135-148.

Baranov, A.V., Tagaev, A.V., Ivleva, O.A., Kotlyarova, O.V. (2018) Kompetentnostnaia sodel' sotrudnika mnogofunktsional'nogo tsentra predostavleniia gosudarstvennykh i munitsipal'nykh uslug [Competence model of an employee of a multifunctional center for the provision of state and municipal services] Gosudarstvennoe i municipal'noe upravlenie. Uchenye zapiski, vol. 4, 22-27.

Beliakova, E. G., Neumoeva-Kolchedantseva, E. V. (2010) Nauchno-metodicheskoe i kadrovoe obespechenie obrazovaniia na sovremennom etape innovatsionnogo razvitiia ekonomiki i sotsial'noi sfery: obzor materialov konferentsii [Scientificmethodological and personnel support of education at the present stage of innovative development of the economy and social sphere: review of the conference materials] Obrazovanie i nauka, vol. 4, 132-141.

Bubnov, Iu. A. (2016) Kadrovaia politika v klassicheskom universitete [Personnel policy at a classical university] Vysshee obrazovanie v Rossii, vol. 5, 118-121.

Chumachenko, E. A. (2012) Finansovyi potentsial formirovaniia regional'nykh innovatsionnykh sistem v ramkakh kontseptsii sozdaniia NIS [Financial potential of the formation of regional innovation systems within the framework of the concept of creating NIS] Terra Economicus, vol. 4-3, 196-198.

Gazieva, I.A., Ballod, Zh.O. (2018) Konfutsianstvo i natsional'nyi traditsionalizm kak osnova postroeniia sovremennoi kadrovoi politiki v sfere gosudarstvennoi sluzhby Respubliki Koreia [Confucianism and national traditionalism as the basis for building a modern personnel policy in the sphere of public service of the Republic of Korea] Srednerusskii vestnik obshchestvennykh nauk, vol. 5, 133-150.

Gazieva, I.A., Shoptenko, V.V. (2020) Komplementarnost' iskusstvennogo i social'nogo intellekta v formirovanii i ocenke upravlencheskih kompetencij kak faktor professional'nogo razvitija studencheskoj molodezhi [Complementarity of artificial and social intelligence in the formation and evaluation of managerial competencies as a factor of professional development of students] In the collection: Best practices in education and career guidance of the Presidential Academy. Collection of methodological materials and articles. The collection is addressed to teachers and staff of the Presidential Academy in order 
to introduce new project approaches to the educational process. Academic editor I. A. Gazieva; Russian presidential Academy of national economy and public administration under the President of the Russian Federation. Moscow, 7-12.

Iakubov, T. V. (2007) Effektivnaia kadrovaia politika kak uslovie realizatsii innovatsionnogo potentsiala predpriiatii stroitel'nogo kompleksa [Effective personnel policy as a condition for realizing the innovative potential of construction complex enterprises]. Terra Economicus, vol. 4-4,196-198.

Korshunov, G. V., Iur'ev, D. O. (2013) Novyi integratsionnyi mekhanizm v sfere nauki, obrazovaniiai biznesa [New integration mechanism in the field of science, education and business] Vysshee obrazovanie v Rossii, vol. 4, 144-147.

Kotliarova, O.V., Mironenko, N.V. (2019) Transformatsiia sistemy dopolnitel'nogo professional'nogo obrazovaniia v protsesse podgotovki kadrov gosudarstvennogo i munitsipal'nogo upravleniia [Transformation of the system of additional professional education in the process of training personnel of state and municipal administration] Upravlencheskoe konsul'tirovanie, vol. 1 (121), 10-19.

Naz'ina, K. S. (2016) Innovatsionnye territorial'nye klastery kak prioritetnoe napravlenie razvitiia promyshlennosti RF [Innovative territorial clusters as a priority direction of the Russian industry development] Gornyi informatsionnoanaliticheskii biulleten' (nauchno-tekhnicheskii zhurnal), vol. 1, 114-121.

Ovakimyan, M.A., Baranov, A.V., Kotlyarova, O.V. Intersection of technological skills and strategic competences in developing the human resource policy in contemporary Russia. CBU International Conference Proceedings. 2018. C. 1-9.

Remorenko, I. M. (2011) Perekhod k innovatsionnoi ekonomike: vozmozhnosti i ogranicheniia dlia sistemy obrazovaniia [Transition to an innovative economy: opportunities and constraints for the education system] Voprosy obrazovaniia, vol. 3 , 54-73.

Roshchin, S., Solntsev, S., Vasil'ev, D. (2017) Tekhnologii rekrutinga i poiska raboty v epokhu interneta [Recruitment and job search technologies in the Internet age] Forsait, vol. 4, 34-43.

Sukhovei, A. F., Golova, I. M. (2016) Obosnovanie transformatsii prioritetov innovatsionno-tekhnologicheskogo razvitiia regionov RF v usloviiakh global'nogo krizisa [Justification of transformation of priorities of innovative and technological development of the Russian regions in the context of the global crisis] Ekonomika regiona, vol. 3, 911-923.

Pavlenko, I. I. (2013) Mesto informatizatsii v strategii razvitiia lingvisticheskogo universiteta [The place of informatization in the development strategy of the Linguistic University] Vysshee obrazovanie v Rossii, vol. 8-9, 71-77.

Zeinalov, G. G., Starodubtseva, L. V. (2013) Sotsial'noe upravlenie innovatsiiami v sfere professional'nogo obrazovaniia (iz opyta raboty mordovskogo gosudarstvennogo pedagogicheskogo instituta im. M. E. Evsev'eva) [Social management of innovations in the field of vocational education (from the experience of the Mordovian State Pedagogical Institute named after M. E. Evseviev)] Integratsiia obrazovaniia, vol. 4, 15-19. 